\begin{tabular}{rr} 
çağdaş & Yaratıcı Drama Dergisi 2015, 10(1), 75-84 \\
drama & www.yader.org \\
\hline
\end{tabular}

\title{
Geleneksel Dansların Tespitinde/ Derlenmesinde Hareket Portesi Notasyon Sistemi (HPNS) Yaklaşımı ve Hareket Kümelerinin Sinıflandırılması
}

\author{
Sonay Ödemiş ${ }^{1}$
}

\begin{tabular}{|c|c|}
\hline Makale Bilgisi & $\ddot{O} z$ \\
\hline DOI: $10.21612 /$ yader.2015.007 & HPNS Dans Analizi Yöntemi'ne göre geleneksel dansların ya da hareket yapılarının \\
\hline $\begin{array}{l}\text { Anahtar Sözcükler } \\
\text { Dans } \\
\text { Halk danslarl } \\
\text { Geleneksel dans } \\
\text { Halk oyunlarl } \\
\text { Notasyon }\end{array}$ & $\begin{array}{l}\text { tespitinde ve derlenmesinde esas alınması gereken yapı unsurları "hareket } \\
\text { kümeleri"dir. HPNS Dans Analizi Yöntemi kullanılarak hareket kümelerinin } \\
\text { tespiti ve derlenmesi sayesinde, üzerinde çalışmalar yürütülen topluluklara ait } \\
\text { danslar ya da hareket yapılar, daha sağlıklı biçimde kayıt altına alınabilecek ve } \\
\text { bilimsel çıkarımlarda bulunulmasının yolları arttırılacaktır. Bu bildiride; HPNS } \\
\text { Dans Analizi Yöntemi kullanılarak hareket kümelerinin sınıflandırılması yaklaşımı } \\
\text { açıklanacak; hareket kümelerinin tespit ve derleme açısından ne denli önem taşıdığl, } \\
\text { ne gibi bilimsel yaklaşımlara destek sağlayacağl ortaya konacaktır. }\end{array}$ \\
\hline
\end{tabular}

The Classification of the Movement Stave Notation System (MSNS) Approach and Movement Clustering in the Determination/Compilation of Traditional Dances

\begin{tabular}{l} 
Article Info \\
\hline DOI: 10.21612 yader.2015.007 \\
\hline Keywords \\
Dance \\
Folk dances \\
Traditional dances \\
Notation
\end{tabular}

\begin{abstract}
According to MSNS Dance Analyze Method, "movement clusters" are the structure elements which should be based on compilation and determination of movement structures or traditional dances. Through the compilations and determinations of movement clusters by using MSNS Dance Analyze Method, we can record dances or movement structures more easily and can create scientific data. In this paper; we will explain classification of movement clusters by using MSNS Dance Analyze Method, and expose its importance in compilations and determinations.
\end{abstract}

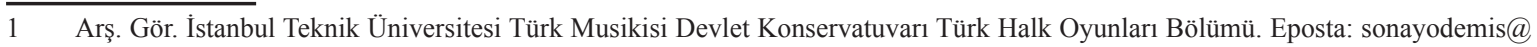
itu.edu.tr 


\section{Giriş}

Geleneksel danslar, icra edildikleri yerlerin yaşayanlarının kültürel dinamiklerine bağlıdırlar. Çünkü bir kültürün yaşayanları, aynı zamanda da onun yaşatanlarıdır. Tıpkı, içinde yaşayanların bulunduğu yüzlerce yıllık evler gibi günün ihtiyaçlarına göre bakımları ve geliştirmeleri gerçekleştirilerek ayakta kalmaları sağlanır. Bu şekilde, güncelleştirmeleri ve bakımları yapılamamış mimari yapıların yok olmasına benzer biçimde, yaşatanlarının ve yaşayanlarının bulunmadığı kültür ürünleri de yok olup gitmeye ya da müzelerdeki yerlerini erkenden almaya mecburdurlar. Geleneksel danslar da kültürü üreten halkın her türlü toplumsal hareketinden çabucak etkilenmeleri sebebiyle, var olabilmek için dinamik kalmak zorundadırlar. Bu dinamikliğin yansıması olan değişimlerin hızı ise peşinen kestirilemez. Bu yüzden geleneksel dansların sabit bir formda tutulması imkânsız, sabit bir formda tutulması için harcanan çaba ise yersizdir.

Ancak, böyle bir gaye göstermeden, içinde yaşanılan zaman aralığında şahit olunan ya da icrası tecrübe edilen geleneksel dansların kaydedilmesine, daha iyi anlaşılmasına ve haklarında geçmişe ya da geleceğe dönük yüksek yaklaşımlı tahminlerde bulunulmasına yarayabilecek herhangi bir yaklaşım mevcut mudur? Mevcutsa, kullanılacak bu yöntem; birden fazla dansçının icrasının ortak paydada kayıt altına alınmasına, dansçılar arasındaki ortak ya da farklı icra özelliklerinin analiz edilebilmesine, icra bölgesinde yaşayanların tarihteki yerleşim yerlerinin tespit edilebilmesine (arkeokoreolojik tespitine) ya da aynı bölgede daha sonraları türeyebilecek dansların tahmin edilebilmesine yardımcı olabilir mi?

$\mathrm{Bu}$ sorulara olumlu yanıtlar verilebilmesi için, hâli hazırda alışkanlık hâline gelen tespit ve derleme biçimlerinin değiştirilmesi gerekmektedir. 20. yy’ın başlarında Türkiye'de sanat alanında da etkisini gösteren modernist yaklaşıma uyumlu biçimde, geleneksel danslar ve müzikler kayıt altına alınmaya başlanmışlardır. Bu kayıt işleminin gayesi ve başarı durumu ne olursa olsun, bugün için muazzam değerli bilgiler sağladıkları yadsınamaz. Ancak yine de bir tekdüzeleşmeye sebep oldukları söylenebilir. Elbette ki “yok olup gitmelerinin mi, yoksa tekdüzeleşmelerinin mi tercih edileceği”, tartışmasının yeri bu çalışma değildir, ancak dolaylı da olsa çalışma ile alakası bulunmaktadır.

20.yy'ın hemen başında Rıza Tevfik imzası ile kaleme alınan "Raks Hakkında" isimli yazıdan edinilen bilgi, henüz zeybek danslarının icrasında bir ortak payda (ortak kalıpta) olmadığını, gelişi güzel (çalımına göre) icra edildiğini haber vermektedir (Tevfik, 1900). Daha öncesi ile ilgili yazılı bir belge şu an için yoktur. Daha sonrasında ise İsveçıte beden eğitimi üzerine eğitim almış ve bu konuda Türkiye'de çokça yayın yapmış (Çapan, 1999) olan Selim Sırrı Tarcan'ın başını çektiği, “Tarcan Ekolü” olarak adlandırılabilecek akım (Ödemiş, 2009) etkisini hızla göstermiştir. Bu ekolün özelliği ise dansların bir düzen içinde sergilenebilmesi için bedenin kayıt altına alınması, yaratıların not edilmesi ya da aktarılmaya çalışılmasıdır.

$\mathrm{Bu}$ okulun bilinçli ya da bilinçsiz takipçileri tarafından özümsenen bir tutum vardır ki o da; dansların nasıl icra edileceğine dair artık kesin yargıların bulunduğu, bu yargıların değişmemesi gerektiğidir. Herhangi bir değişiklik kolaylıkla kabul görmediği gibi, çoğunlukla da "kültürün bozulması" olarak algılanmakta ve tepki görmektedir. Tarcan'ın aslında iyi niyetli olarak görülmesi gereken; zamanın kadın-erkek ilişkilerine ve eğitilmemiş bedenlere bir tepki olarak giriştiği derleme ve yaratım çalışmaları (Tarcan, 1926; Çapan, 2002), çıkış yönünde bir farklılaşma ile kullanılmaya 
başlanmıştır. Bu ekolün birikimi ve «milli oyun kavramı»nın gelişmesi sonucunda, takip eden pek çok çalışmada, artık «geleneksel dansların kabul görmüş doğruları» bulunmaktadır. Başlangıçta zeybek türü geleneksel dansların tespiti ile girişilmiş görünen bu uğraş, sonraları tüm Türkiye`ye yayılmıştır. $\mathrm{Bu}$ yaklaşıma uyum gösteren ve dansların bilinen «doğru icra biçimlerini» okuyucularına aktarma çabalayan kitapların yazarları² arasında Sırrı Numan (Numan, 1929), Osman Bayatlı (Bayatl1, 1943), Kasım Ülgen (Ülgen, 1944/1-2-3), Şerif Baykurt (Baykurt, 1965), Ahmet Saçan (Saçan, 1974), Enver Keskin (Keskin, 1975), Cemil Demirsipahi (Demirsipahi, 1975) ve Mehmet Öcal Özbilgin (Özbilgin, 2012) gösterilebilir.

Tüm bu yaklaşımlar, sadece basılı yayınlarda değil, aynı zamanda ve çok daha etkin biçimde "halk dansları topluluklarının yarıştırıldı̆̆ı" yarışmalarda ${ }^{3}$ kendini göstermektedir. Hatta bu yarışmalarda yeni tespit edilen, derlenen ve "yaratılan" geleneksel dansların sergilenmesinin kazandırdığı sükse ve maddi imkânlar, geleneksel dansların tespitindeki/ derlenmesindeki heyecanı ve isteği arttırmıştır. Derleme ve tespit çalışmalarının ilgililerle yazılı olarak paylaşılması, gösteri ya da yarışma topluluklarınca hızla tüketilmesinin hızına yaklaşamamıştır. Bu hıza doğru orantılı olarak yapılan yayınların sayısında ciddi bir düşüş görülmekte, bu yüzden de ilgililere gerekli bilgilendirme yapılamamakta ve bu çalışmalara ait görsel kayıtlar ise kişisel arşivlerde çürümeye bırakılmaktadır. Belki de yeni tespit edilen dansların ilgililerle paylaşılmasından duyulan heyecanın, Baykurt'un makalesinin (Baykurt, 1958) başlığında verilen boyutta yeniden yaşanması bir hayal olarak kalacaktır: "Yeni Derlenen Trakya Halk Danslarl”.

Çalışmaların yazılı biçimde paylaşııması ya da paylaşılmaması bir yana, geleneksel dansların tespiti ve derlenmesi olağanca hızıyla devam etmektedir. Ancak bu tespit ve derleme çalışmaları, Tarcan Ekolü'nün devamı olarak tanımlanabilecek; belirli bir doğrunun muntazaman aktarılması, derlenip toparlanması, izlenebilecek hâle getirilmesi, derlemeci müdahalesi olmasına rağmen artık değiştirilmemesi amaçlarını ve beğeni kaygılarını taşımaktadır.

Anlaşılan o ki, son dönemlerde yapılan geleneksel dans tespiti ve derleme çalışmaları; çalışılan sahanın en iyi icracısının tespit edilerek işe başlanması, icracı/ların (eşlik müziği icracısı dâhil) icrasının kaydedilmesi ve görüntüleri kaydedilen dans unsurlarının tespiti/derlemeyi yapan kişinin beğenisine göre yeniden düzenlenmesi silsilesini izlemektedir. Bu tür tespit ve derleme çalışmalarının derleme notları genelde bulunmadığından, yine pek çoğu için aşağıdaki şu sorular yanitsız kalmaktadır.

- Tespit ve derleme öncesi için: Sahanın en iyi dansçısı/ları neye göre seçilmiştir? Seçim yapılırken; tespiti/ derlemeyi yapan kişi mi yoksa yörenin söz sahibi kişileri mi belirleyici olmuştur? En iyinin/lerin seçimi yapılırken yaş ve icracının bedenini istediği yeterlikle kullanılması ne derece önemlidir? İcracının bedensel dezavantajları göz önüne alınmış mıdır? İyi icracı olmadığı varsayılan kişiler kayıt altına alınmış midir?

2 Bu alanda yapılan pek çok yayında benzer özellikler bulunduğu için, bu bildiride yalnızca birkaçı örnek olarak sunulmuştur. Söz konusu konu ile ilgili daha fazla kaynağa Ahmet Şenol tarafından 1991 yılında yayımlanan Türk Halk Oyunları Bibliyografya Denemesi isimli kitabın (Şenol, 1991) kılavuzluğunda ulaşılabilir. Ayrıca anılan bibliyografya çalışmasının güncelliğini yitirmiş olması bakımından, bu tür bibliyografik çalışmalara da ihtiyaç duyulduğunu belirtmekte fayda bulunmaktadır.

3 Doğru icranın tespitinin veya derlemesinin yapıldığına olan inancın, "doğrusu tespit edilen dansların” yapısına zarar verdirilerek yarışma kriterleri çerçevesinde yeniden şekillendirilmesi ile bile kırılmaması anlaşılamayan bir konudur. Eğer söz konusu yarıştırılma kriterlerinin, tespiti yapılan geleneksel dansların yapılarına zarar vermediği düşünülüyor ise, akla gelebilecek ilk soru: tespit ve derlemelerin kriterlerin müsaade edeceği ölçütlere göre mi yapıldı̆̆ıdır. 
- Tespit ve derleme esnası için: İcranın kaydedilmesi sırasında tercih edilen mekân, suni midir (kayıt için bir araya gelinen yer) yoksa doğal (icracının icrasına denk gelinen yer) mıdır? Kayıt süresi kısıtlı mıdır? İcracı/lar eşlik müziklerini kendileri (ağızdan ya da çal-oyna biçiminde) mi icra etmektedirler? İcracı/ların yorgunlukları dikkate alınmış mıdır? Görüntü kaydının yapılmasında, kayıt cihazının kapsamı dışında kalan alanda, icracı/ları etkileyebilecek unsurlar söz konusu mudur? İcra esnasında sözlü ya da başka bir yöntem ile icracıyı/ları yönlendirme söz konusu mudur?

- Tespit ve derleme sonrası için: İcracının icrası olduğu gibi kabul mü edilmektedir, yoksa kayıt edilen icra/lar sırasında uygulanan dans unsurlarından, beğeniye göre yeniden sıralanması esnasında derleme dışı bırakılanlar var mıdır? İcracının stil analizi yapılmış mıdır?

$\mathrm{Bu}$ ve benzeri sorular daha da arttırılabilir. Ancak fark edileceği üzere yukarıdaki sorular, dansın doğru icra biçiminin tespit edilmesi, ilgililere sunulması ve dış etmenlerden korunarak devamlılığının sağlanması amaçlarını taşınması durumlarında geçerlidir. Bu tür amaçların kesin olarak benimsenmesi, "dansın bir bütün olarak tespit edilmesi” ihtiyacını doğurmaktadır. Yani benzetme ile açıklamaya çalışılacak olursa; bir dilde yaşayan kelimelerin bir sözlükte toplanması yerine, o dilde daha önce kurulmuş tüm cümlelerin kayıt altına alınması gibi bir talihsiz uğraştır. Cümlelerin kayıt altına alınması işleminin sonsuzluğu ve cümleleri okuyanların beğenisine dayalı olarak çıkarılan kötü kelimeler (küfürler, argo tabirler, yerel kullanımlar vb.) kayıt dışı kalmış olacaklardır. Hangi kelimenin ne zaman ve neden kayıt dışı bırakılacă̆ 1 da tamamen kayıt edenin vicdanına bırakılmış durumdadır. Kayıt altına alan kişi de, doğru cümleleri (hatalarından arındırılmış) tespit etme mecburiyetine dayalı olarak bask1 hissetmektedir.

$\mathrm{Bu}$ durumda, dans için tespiti /derlemeyi yapan kişinin icracılar arasından" doğru icrayı yapanı bulmaya çalışması" ya da "diğerlerine nazaran daha fazla beğeni toplayarak değer atfedilen dans unsurlarının birden fazla icracıdan toplanarak bir araya getirilmesi” mecburileşmektedir. Profesyoneller tarafindan sarf edilen çabaya istinaden, "doğrusunun tespit edildiğine olan güçlü inanç" ise, halk tarafından da benimsenirse, yeni katı kuralların suni biçimde oluşturulmasına, yeni üretimlerin yapılmasından çekinilmesine, hatta yeni yaratımların ise olası tepkilerden çekinilerek “anonim gibi gösterilmeye çalışılmasına” sebep olabilmektedir.

Hâlbuki “dansın bir bütün olarak tespit edilmesi” çabası, tespit ya da derleme anında değerli görülmeyen pek çok dans unsurunun fark edilememesine, kayıt altına alınamamasına ve yitirilmesine sebep olmaktadır. Kısacası, kârdan çok zararı dokunan bir yöntemdir. Ancak çok sayıda bilginin devamlı tartışılması ile yorulmak yerine, tek bir doğru üzerinden hareket edildiği için kolayc1 ve daha pratiktir. Böyle bir durum ile karşı karşıya kalınmaması için ise tespit çalışmalarında izlenen yöntemin değiştirilmesi, dansın bir bütün olarak tespit edilmesinden ya da farklı kişilerin icralarının “ayıklanmış bir kolaj” hâlde sunulmasından vazgeçilmesi gerekmektedir.

Bu bildiriye konu olan yeni yaklaşım; Hareket Portesi Notasyon Sistemi (HPNS) Dans Analizi Yöntemi kullanılarak "sahada icra edilen hareket kümelerinin tespit edilmesine" dayanmaktadır. HPNS yaklaşımı ile hem tespitlerin ölçülebilir kriterler ile yapılmasına hem kayıt dışı bırakılan kültürel unsurun sayısının en aza indirilmesine hem de bu ürünler hakkında bilimsel çıkarımların yapılabilmesine imkân sağlanacağı öngörülmektedir. 


\section{Yöntem}

Hareket Portesi Notasyon Sistemi (HPNS) (Ödemiş, 2012/1), bedende uygulanan anatomik hareketleri temel alarak dansın ya da diğer beden hareketlerinin yazıya geçirilmesini ve analiz edilerek verilerin yorumlanmasını (Ödemiş, 2012/2) (Ödemiş, 2012-3) sağlayan bir sistemdir.

Gerek dansın/beden hareketinin yazıya geçirilebilmesini gerekse analiz edilebilmesini, dansın yapısal unsurlarına ayrılması sayesinde gerçekleştirir. HPNS'ye göre dansın yapısal unsurları -büyükten küçüğe-; bölüm, hareket cümlesi, hareket kümesi, pozisyon ve harekettir. Bu unsurlar birbirlerine ayrılamaz biçimde bağlıdırlar ve birbirlerini oluştururlar. En küçük yapısal unsur olan hareket, eklemlerde oluşan anatomik hareketlerdir ve bu anatomik hareketler "pozisyon"ları, pozisyonlar ve aralarında uygulanan geçişler "hareket kümeleri”"ni, hareket kümeleri ve aralarındaki geçişler "hareket cümleleri”’ni, hareket cümlelerinin birleşimleri ise dansın bölümlerini meydana getirirler. Diğer bir açıdan bakıldığında yapısal çözümlemesi yapılmış bir dans, yazılı bir kompozisyona benzetilebilir. Nasıl ki kâğıda çizilen çizgilerin anlamlı birleşimleri harfleri, harfler heceleri, heceler cümleleri, cümleler paragrafları ve paragraflar kompozisyonun tamamını oluşturursa, dansta da durum aynıdır.

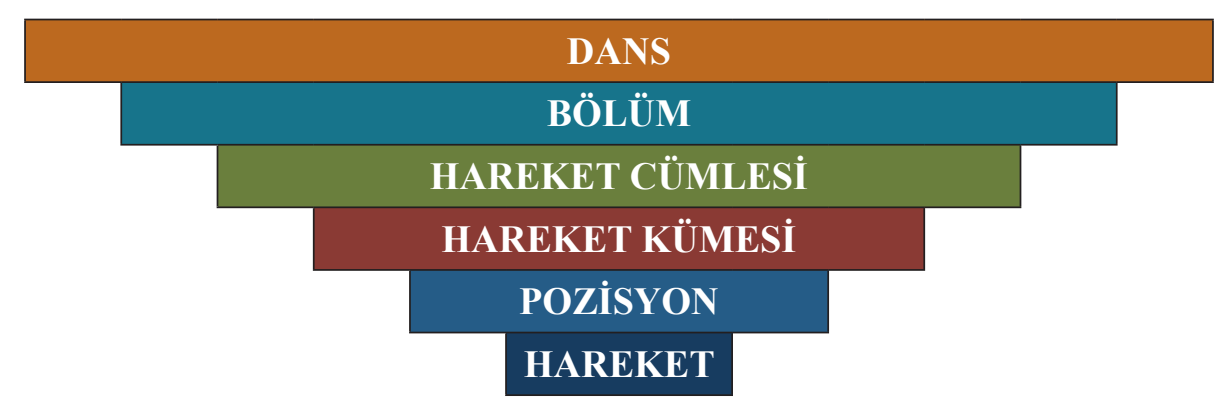

Şekil 1. HPNS'ye göre dansin yapısal unsurlart

HPNS ile bir dansın/beden hareketinin yazıya geçirilmesi, yapısal unsurlardan olan pozisyonların; alt ekstremite, üst ekstremite ve gövde olarak ayrıştırılıp numaralandırılmasından sonra, kendi işaretleme alanlarına içerdikleri anatomik hareketlerin açıları ile birlikte işaretlenmesi ile başarılabilmektedir. İşaretlemesi yapılan pozisyonlar arasındaki geçişler (sıçramalar, dönüşler, temas ve ağırlık değişimleri vb.) ise ayrıca detaylandırılır. Geçişleri ve pozisyonları ile birlikte, anlamlı olduğu varsayılan pozisyon grupları "hareket kümeleri” olarak tanımlanırlar. Ancak bu tanımlamalar detaylı biçimde aktarıldığı için, bir diğer araştırmacının aynı kabullere itiraz ederek değiştirebilmesine olanak tanınmış da olur.

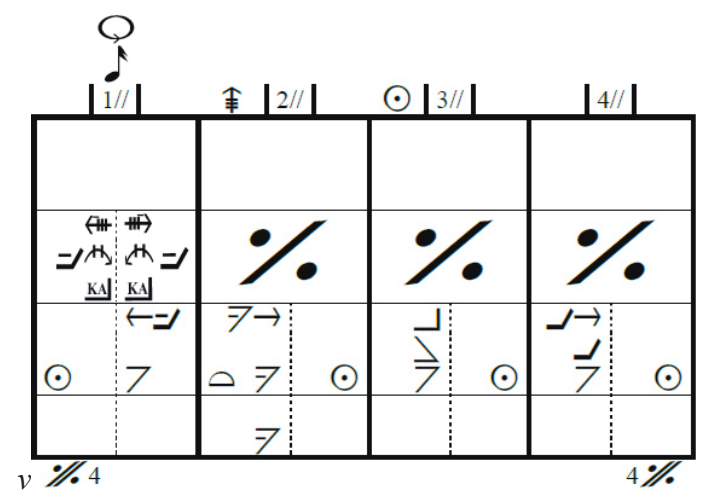

Şekil 2. HPNS Yazım Örneği (Aydın Harmandalı Zeybeği GHK-0, ÜHK-3, AHK-4)

(Ödemiş, 2012-2) 
HPNS'ye göre, pozisyonların bilinçli diziliminden elde edilen hareket kümeleri, ana tabloyu oluşturan yapboz parçalarına benzerler ve tek başlarına bir bütünlük sergileyemeseler de tek başlarına uygulanabilirler. Yapboz parçalarına benzeyen bu hareket kümeleri, cümleleri oluşturan kelimelere de benzetilebilir. Kelimeler tek başlarına pek bir anlam ifade edemedikleri zaman, bir araya gelerek bir cümle oluştururlar. Hareket kümeleri de tıpkı bu şekilde, birbiri ardına ve eşlik müziğine de uyum sağlayacak biçimde ard arda getirilirler. Oluşturulan bu dizilime HPNS'de "hareket cümlesi" denir ve cümle uzunlukları çoğu zaman eşlik müziği ile sınırlı olsa da, hareket kümelerinin dizilimleri farkl111k gösterebilmektedir.

Geleneksel olarak dansçıların birbirine kopmayan temaslar (bağlı tutuşlar) ile ilişik olduğu danslarda bile, kişisel farklılaştırmaların sergilenmesi olanaklıdır. Halay ya da bar türü geleneksel danslardaki, üst ekstremitenin kesintisiz temasının bulunduğu zamanlarda bile bireylerin alt ekstremitelerinde sergiledikleri farklı hareket kümeleri bu yapılanmalara iyi bir örnek teşkil eder. Hareket kümelerinin farklı dizilimlere sahip olması, uzun sürelerde icra edilen dansların, kişilerin tercihlerine göre şekillendirilerek "sıkılmaktan" kurtulmaya çalışılması, yeni hareket kümesi yaratımlarının oluşmasına sebep olmaktadır. Yaratılan bu yeni hareket kümelerinin her biri HPNS için oldukça değerlidir. Çünkü -özellikle bireysel danslarda- kişilerin icra ettikleri danslarda, dansa eşlik eden müzik ile uyumlu olarak ardı ardına sergilediği hareket kümeleri, aynı zamanda icracı/ların repertuvarını da ortaya koymaktadır. Her ne kadar aynı yörede yetişse bile, her bireyin kendi yaşamı, kendince bir hayat ve öğrenme tecrübesi var. Bu bakımdan her bireyin kendisi için geliştirdiği hareket kümesi repertuvarı eşsizdir ancak yöredeki diğer hareket kümeleri ile benzerlikler gösterebilir.

Yaygınlaşmış uygulamaya göre "dansın kabul görmüş doğru icrasının tespit edilmeye çalışılması”, kişisel yetenek ve repertuvarların varlıklarını görmezden gelerek, eşlik müziği ile icra edilmesi alış1lagelmiş hareket kümesi dizilimlerinin (hareket cümlelerinin) ezberlenmesi ve ezberletilmesine sebep olmaktadır. Oysaki bu yaklaşım, "dansların korunması" gibi masum bir refleks iken, yeni yaratımların ve çeşitliliklerin görmezden gelinmesine, doğrudan dansın gelişiminin yolunun tıkanarak geleneksel dansların kalıplaşmasına neden olmaktadır. Yukarıda daha önce de değinildiği üzere, beden hareketlerinin tespit edilip kataloglanmasında cümle dizilimlerinin (hatta dansların bütün olarak) kaydedilmeye çalışılması, cümlelerden oluşan bir sözlük yaratılmaya çalışılmasına denk gelecek yersiz bir uğraştır.

HPNS'de önerilen yöntem; dansları bir bütün olarak tespit etmek yerine, inceleme için belirlenen alanda icra edilen tüm hareket kümelerinin (alt ekstremite, üst ekstremite ve gövdede) ayrı ayrı tespit edilmesidir. İcracılar tarafından sergilenen her dizilim (hareket cümlesi, hatta dansın tamamı) "kişiye özel" " ya da bireysel olarak tanımlanmalı ve mümkünse arşivlenmelidir.

$\mathrm{Bu}$ yöntem, kelimelerden (kelimelerin o dildeki olumlu ya da olumsuz anlamlarına aldırış edilmeden ve seçilmeden) oluşturulan sözlüklerin aynısının, geleneksel dansların icrasında kullanılan hareket kümelerinin tespitinde de oluşturulmaya çalışılmasıdır. Bu sayede, "icrasının doğru olduğuna inanılan dansın tespiti” sırasında akıllarda oluşturulan ve yukarıda örneklenen soruların pek çoğu bertaraf edilmiş olacaktır.

Çünkü incelemealtınaalınan sahadaicra edilen hareketkümelerinintespitedilmesiaşamasında, o bölgede icrasıyla ünlenmiş kişilerin özellikle aranıp bulunmasına ihtiyaç olmayacağından; yukarıda tespit öncesinde herhangi bir icracının seçilmesine dair tüm sorular geçerliliğini yitirecektir.

4 Kişiselliklerden arındırılan bazı toplumsal ritüeller bu genellemenin dışında bırakılmalıdır. 
HPNS'ye göre, hareket kümelerinin tespiti öncesi, esnası ve sonrası için dikkat edilmesi gereken hususlardan bazıları şunlardır:

• “Tek bir doğru icranın kabulü” olmayacağından ve her icracının icrası kendine has bir değer taşıdığından, icracının; en iyi, en kötü, en yaşlı, en genç, en iyi fiziki kondisyona sahip, en uzun süre sahada yaşayan vb. ya da herhangi bir başka belirtecine ihtiyaç duyulmamaktadır. Gözlemlenen her dans unsuru kaydedilmelidir.

- Kişi kendisini hangi cinsiyete mensup olarak düşünüyorsa aynen kabul edilerek, cinsiyet ayrımı yapılmamaktadır.

- İcranın gerçekleştiği mekan da önemini yitirmektedir. Çünkü icracının her bir icrası değerli olacağından ve suni ya da doğal mekânlardaki icrasının tamamı kayıt edilmeye çalışılacağından mekân üzerine ayrıca dikkat çekilmesi gerekmemektedir.

- İcranın, sadece dansa eşlik eden müzik ile birebir uyum sağlayan bölümünün dikkate alınması yerine, icraya niyetlenildiği andan itibaren tüm süre performansın kendisi olarak kabul edilmeli, özellikle müzik eşliği olmayan kısımlardaki icralar gözden kaçırılmamalıdır.

- İcracıların icra esnasındaki bedeni yorgunluk, uygulayabilirlik ve dezavantajl11ık durumları tespit edilmeye çalışılmalıdır. Eğer böyle bir imkan yaratılabilir ise, icracının yapmak istediği hareket kümelerinin tamamını «istediği şekilde» icra edip edemediği üzerine söyleşi gerçekleştirilmelidir.

- Video görüntü kaydının alınması için gerekli donanım sağlanarak, mümkünse icranın tamamını çekebilen yeter sayıda cihaz kullanılmalı, ayrıca icra ve kayıt yapılan alanın tamamı eş zamanlı olarak ayrıca kayıt altına alınarak, dış etmenler tespit edilmelidir.

- İ́cra esnasında, tespit çalışması yapan ya da yapanlardan biri / birkaçı olsa bile en küçük yönlendirme, icranın bir parçası olarak kabul edilmelidir.

- İcra/lar sırasında kayıt altına alınan her hareket kümesi, ait olduğu zamanın beğenilerinden bağımsız olarak tespit edilmelidir. HPNSıye göre, icray1 kaydeden kişinin beğeni algısının, icrayı gerçekleştirene göre farklı olabileceği ve değerlendirmelerin öznel olabileceği unutulmamalıdır.

- Her hareket kümesinin kendine has bir değeri olacağından, suni yollar ile bu hareket kümeleri arasından derlemelerin yapılması ve yaygınlaştırılmaya çalışı1ması uygun olmayacaktır. Bu sebeple, birden farklı icracının uyguladığı hareket kümelerinin bir dizilimine ihtiyaç duyuluyor ise, bu dizilim de "tespiti yapılan sahadan etkilenerek kendi dizilimini yapan ve araştırmaya konu olan bir başka icracının icrası” olarak değerlendirilmelidir.

- Araştırmaya konu olan her inceleme sahası ve her icracı için ayrı bir kataloglama dosyası açılmalıdır. Bu dosyaların güncel tutulması için gerekli özen gösterilmelidir.

- Her icracının hareket kümesi repertuvarı, genel ve özel hareket cümlesi dizilimleri, dans ve eşlik müziği arasındaki tutarlılıkları vb tüm detaylar; bu detayları değiştirebilecek farklı durumların oluşması hâlinde (göç, aile bireylerinin vefatı/ doğumu/düğünü/ sünneti/vb, doğal afetler, farklı mevsimler ve kıyafetleri, diğer toplumsal olaylar vs.) mümkünse yeniden incelenmelidir. 
HPNS kullanılarak ortaya çıkarılan kataloglamalar sayesinde, dansın yapısal unsurlarının tamamının mukayesesinin yapılabilmesi mümkün ve sahanın yorumlanması için gereklidir. Örnek olarak; icracıların, hareket kümesi repertuvarları, stilleri, genel yapıya uyumları vb. pek çok değer karşılaştırılabilir. Bu değerlerin başında elbette ki hareket kümeleri gelmektedir.

Hareket kümelerinin, hareket cümlelerinin ana yapılarındaki kullanımlarına ve birbirleri ile karşılaştırılmalarına göre alt kategorileri bulunmaktadır. HPNS kullanılarak yürütülen mevcut araştırmalara göre (Ödemiş, 2012/2) (Ödemiş, 2012/3) : hareket cümlesi içindeki kullanımlarına göre hareket kümeleri; "başlangıç hareket kümeleri”, "değişken hareket kümeleri”, "serbest hareket kümeleri" ve "sonlandırıcı hareket kümeleri" olarak 4 alt kategoriye ayrılmaktadırlar.

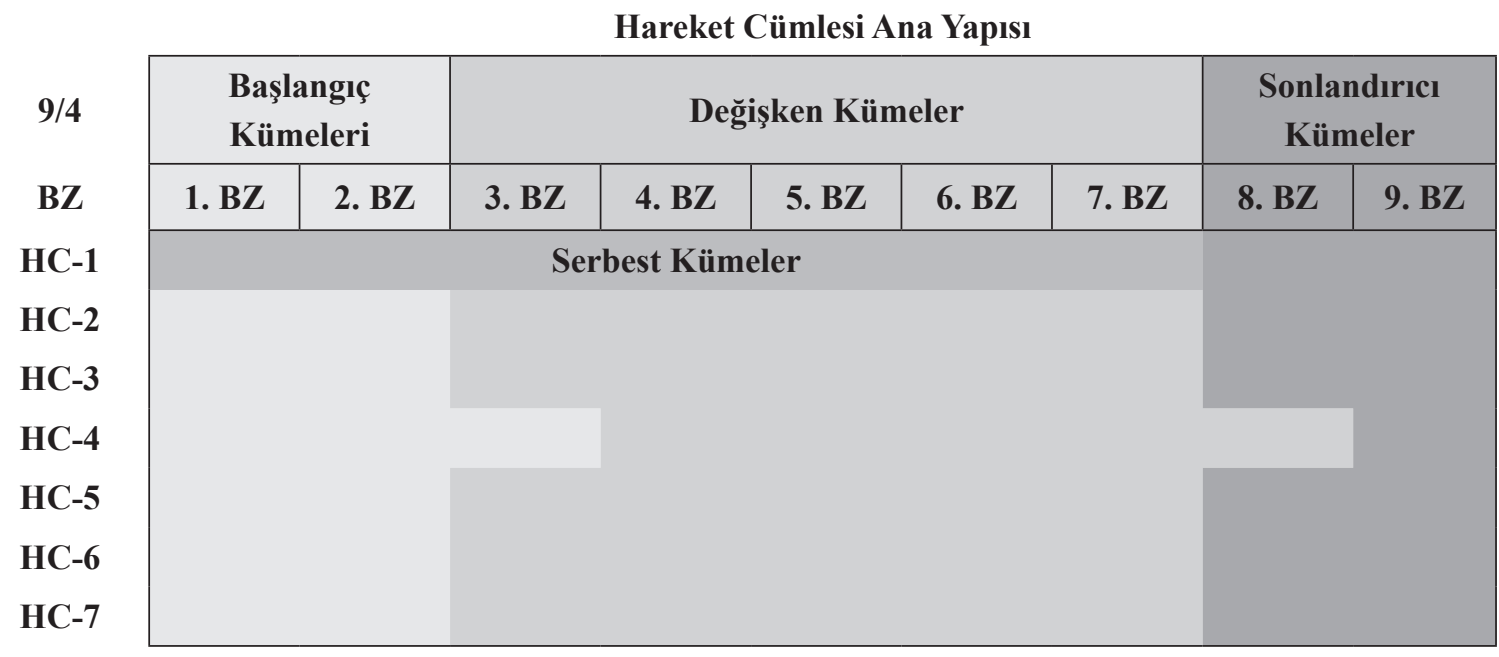

Şekil 3. Hareket Cümlesi Ana Yapısını oluşturan Hareket Kümeleri Örneği (Ötme Bülbül Zeybek Dansı) (Ödemiş, 2012/3)

Başlangıç hareket kümeleri: Hareket cümlelerinin ana yapısının oluşturulmasına başlangıçta kullanılması, icracılar tarafından alışkanlık/ geleneksel hâline getirilmiş olan hareket kümeleridir.

Sonlandırıcı hareket kümeleri: Hareket cümlelerinin ana yapılarının oluşturulmasına, eşlik müziğinin (genellikle) ölçü bitimlerine yakın olarak icra edilmesi icracılar tarafından alışkanlık/ geleneksel hâline getirilmiş olan hareket kümeleridir. Hareket cümlelerinin birbiri ardına aynı dizilim ve içerikle tekrar edildiği durumlarda, genellikle hareket cümlelerinin birbirinden ayrıştırılmasında en etken rolü üstlenen hareket kümeleridir.

Değişken hareket kümeleri: Başlangıç ve sonlandırıcı hareket kümelerinin belirlendiği ve yöresel bazda kalıplaşmışlık gözlemlenebilen danslarda çok ağırlıkta olmak üzere, başlangıç ve sonlandırıcı hareket kümelerinin arasındaki icra süresini değerlendirmek üzere uygulanacak hareket kümeleridir. Dansın hareket kümelerinin isimlendirilmesinde yaygın olarak kullanılırlar.

Serbest hareket kümeleri: Genellikle "tamamıla irticalen” ya da "eşlik müziğinin yönlendirmelerine ihtiyaç duyulmayan icra sürelerinin kullanılması” amacıyla uygulanan ve aslında başlangıç, sonlandırıcı ve değişken hareket kümelerinin de rastgele bir biçimde icra edildiği hareket kümesi grubudur.

Geleneksel dansların icralarında yörede yaygın olan bazı kabullerin varlığı da yadsınmamalıdır. Bu gibi durumlarda, dansların oluşum süreçlerinde etkili olan birtakım sembol hareketler ve alışılagelmiş dans unsuru kalıpları karşımıza çıkabilmektedir. Bu gibi durumlarda 
hareket kümeleri danslardaki kullanımlarının genelleşmesi yahut özelleşmelerine bakılarak 3 farklı alt gruba ayrilırlar. Bu gruplar; "temel hareket kümeleri”, "genel hareket kümeleri” ve "özel hareket kümeleri"dir.

Temel hareket kümeleri: İnceleme altına alınan sahada icra edilen dansların sayıca büyük çoğunluğunda ve dansın icrasına doğrudan etkide bulunan hareket kümeleridir. Temel hareket kümeleri, dansın kendisi içinde de en temel olarak kullanılan hareket kümeleridir. HPNS〉de kullanımları şu anda kısmen formüle ${ }^{5}$ edilmiştir (Ödemiş, 2012-3) ve formülasyon çalışmaları hâlen devam etmektedir.

Genel hareket kümeleri: İnceleme altına alınan sahada icra edilen dansların genelinde etkinliğine bakılmaksızın icra edildiği tespit edilen hareket kümelerine bu isim verilmektedir.

Özel hareket kümeleri: İnceleme altına alınan sahada icra edilen dansların ya da varyasyonlarının yalnızca birinin icrasında uygulandığı tespit edilen hareket kümeleridir. $\mathrm{Bu}$ tür hareket kümeleri oldukça belirgindir ve aynı zamanda dansın temel hareket kümesi olarak da değerlendirilmeleri mümkündür.

Ayrıca, hareket kümelerinin sınıflandırılmasında, hareket kümelerinin içeriğinde yer alan pozisyonlar da etkin olabilmektedir. Bu sinıflandırmaya göre, hareket kümelerinin birbirinin aynı, benzeri ya da varyasyonu olup olmadığına kanaat getirilebilir. Yukarıda da bahsedildiği üzere HPNS notalaması, bir dansın portesi üzerinde belirlenmiş alanlara "pozisyon temelli ve anatomik hareket içerikli" işaretlemeler sayesinde uygulanmaktadır. Notalamanın temelini pozisyonlar oluşturmaktadır. Elbette ki pozisyonlardan, hareket kümelerinin birbirinden ayrılmalarında da yararlanılmaktadır. Pozisyonlar ve pozisyonları oluşturan anatomik hareketler temel alınarak hareket kümelerinin sınıflamaları yapıldığında ise; aynı hareket kümeleri, benzer hareket kümeleri, varyasyon hareket kümeleri ve farklı hareket kümeleri olmak üzere 4 alt sınıf oluşturmak mümkündür. Bu sınıflamayı izah etmek için, hayali bir alt ekstremite hareket kümesinin varlığını ve bu kümeyi oluşturan pozisyonların numaralarının $0,1,2,3,4,5$ olduğunu ve dizilimlerinin ise (AHK-1=AP1+AP4+AP3+AP0+AP2) olduğunu kabul edelim.

HPNS hareket kümeleri üzerinden "pozisyon temelli aynılık testi” uygulanacak olursa aşağıdaki sonuçlara ulaşılacaktır.

Aynı hareket kümeleri: teste tabi tutulduğu hareket kümesi ile birebir örtüştüğü hareket kümeleridir. Simetrik hareket kümeleri de bu gruba dâhil edilir.

Benzer hareket kümeleri: teste tabi tutulduğu hareket kümesi ile tutarlı biçimde (vurgu, ana pozisyon vb) uyuştuğu hareket kümeleridir. Örnek olarak teste tabi tutulan hareket kümesini AHK-2 olarak kabul edersek ve içeriği, verilen biçimde olursa benzer hareket kümesi olarak değerlendirilir. $(\mathrm{AHK}-2=\mathbf{A P 1}+\mathrm{AP5}+\mathbf{A P 3}+\mathrm{AP} 6+\mathbf{A P 1})$

Varyasyon hareket kümeleri: teste tabi tutulduğu hareket kümesinin pozisyonlarının dizilimine eşitlik gösteren sayıda pozisyonun, içeriklerindeki anatomik hareketlerin yalnızca açılarında farklılık gösteren hareket kümeleridir.

Farklı hareket kümeleri: aynı, benzer ya da varyasyon hareket kümeleri kapsamında dahil edilemeyen tüm hareket kümeleri, birbirinden farklı kabul edilir.

$5 \quad$ Şu an için HPNS'de temel hareket kümesi tespiti; dansın toplam süre değeri üzerinden, hareket kümelerinin her birinin kullanım oranları çıkarıldıktan sonra, en yüksek oranlara sahip olanlar arasından "tüm hareket cümlelerinde kullanılmış olma" kriteri işletilerek yapılmaktadır. 


\section{Sonuç}

Sonuç olarak; HPNS Dans Analizi Yöntemi kullanılarak yapılacak karşılaştırmalar ve sınıflamalar sayesinde, inceleme altına alınan sahada icra edilen dansın yapısal unsurlarından hareketle birçok genel kanaate, beğeni faktöründen uzak biçimde ulaşılması sağlanacaktır. İnsanların öznel beğenilerinin uzağında yürütülecek araştırma faaliyetlerinin ide geçmiş ve gelecek ile yüksek tutarlılığa sahip varsayımlarda bulunulmasına katkı sağlayacağı çok açıktır.

$\mathrm{Bu}$ ve benzeri yaklaşımların arttırılarak devam ettirilmesi neticesinde; geleneksel dansların ülke genelinde sınıflandırılmasının nesnel bir bakış açısı ile yeniden değerlendirilmesi, mevcut dans örneklerinin mümkün olduğunca çok niteliği ile birlikte sonraki kuşaklara aktarılması, bir bölgede yerleşen kişilerin kültürel akrabalarının tespitinin yapılması, hedef alınan bir bölgede ve öngörülen bir zaman diliminde ortaya çıkması, muhtemel dans biçimlerinin şimdiden tahmin edilebilmesi gibi şu anda birer ütopik düşünce gözüyle bakılan pek çok fikir kendilerine eylem sahası bulabilir.

\section{Kaynakça}

Bayatl1, O. (1943). Ege'de zeybek oyunlart ve havaları. İzmir: Nefaset Matbaası.

Baykurt, Ş. (1958). Yeni derlenen trakya halk dansları. Türk Folklor Araştırmaları, (110).

Baykurt, Ş. (1965). Türk halk oyunlarl. Ankara: Halkevleri Genel Merkezi.

Çapan, M. Ş. (1999). Türk sporunda Selim Sırrı Tarcan (1874-1957). Muğla: Ün Yay.

Çapan, M. Ş. (2002). Selim Sırrı Tarcan'ın zeybek oyun derleme çalışmaları. Muğla Sıtkı Koçman Üniversitesi Sosyal Bilimler Enstitüsü Dergisi.

Demirsipahi, C. (1975). Türk halk oyunları. İstanbul: Yapıkredi Bankası Yayınları.

Ekici, M. (2003). Selim Sirrı Tarcan'ın bir makalesi: "Yeni zeybek raksı". Milli Folklor, 10-25.

Keskin, E. (1975). Enver Keskin 'le halk oyunları öğretimi. Ankara: Kadıŏlu Matbaası.

Numan, S. (1929). Erzurum oyunlart ve oyun havaları. İstanbul: Halk Bilgisi Derneği.

Ödemiş, S. (2009). Zeybek danslarında değim. (4), 28-29.

Ödemiş, S. (2012). Halk oyunları notasyon sistemi denemesi-hareket portesi. Yayımlanmamış yüksek lisans tezi, İTÜ SBE Türk Müziği Programı, İstanbul.

Ödemiş, S. (2012). Aydın Harmandalı Zeybeği'nin yapısal ve anatomik analizi. Türk Tarihinde Efe ve Zeybek kültürü Seтроzyumu Bildirileri (266-296). İzmir: T.C. Ödemiş Belediyesi Kültür Yayınları.

Ödemiş, S. (2012). Ötme Bülbül Zeybeği’nin yapısal ve anatomik analizi. 1. Uluslararası Müzik Araştırmaları Sempozyuтu, "Kültürel Doku". KATÜ Konservatuarı, Trabzon.

Özbilgin, M. Ö. (2012). İzmir zeybek oyunları. İzmir: Ege Üniversitesi.

Saçan, A. (1974). Milli oyunlarımız. Ankara.

Şenol, A. (1991). Türk halk oyunları bibliyografya denemesi. Ankara.

Tarcan, S. S. (1926). Yeni zeybek raksı. İstanbul: Vatan Matbaas1.

Tevfik, R. (1900). Raks hakkında. D.B. Ömer içinde, Nev Sal-i Afyyet Salname-i Tibbi. İstanbul.

Ülgen, K. (1944). Doğu Anadolu oyunlarl ve havaları (Kitap 1- Erzurum oyunları). C. Matbaası (Dü.). İstanbul: Kars Halkevi.

Ülgen, K. (1944). Doğu Anadolu oyunları ve havaları (Kitap 2- Kars oyunları). C. Matbaası (Dü.). İstanbul: Kars Halkevi.

Ülgen, K. (1944). Doğu Anadolu oyunları ve havaları (Kitap 3- Artvin oyunları). İstanbul: Kars Halkevi. 